\title{
Functional Applications of Monoclonal Antibodies in Cancer Therapy via Drug Targeting Approach
}

\author{
Jagadevappa Patil \\ VT's Shivajirao S Jondhle College of Pharmacy, Asangaon-421 601, Shahapur, Thane, Maharashtra, India
}

*Corresponding author: Jagadevappa Patil, VT's Shivajirao S Jondhle College of Pharmacy, Asangaon-412 601, Thane, Maharashtra, India, Tel: 9448816812 ; E-mail: pharmajspatil@gmail.com

Received date: September 20, 2016; Accepted date: September 29, 2016; Published date: October 05, 2016

Copyright: ( 2016 Patil J. This is an open-access article distributed under the terms of the Creative Commons Attribution License, which permits unrestricted use, distribution, and reproduction in any medium, provided the original author and source are credited.

\section{Introduction}

In last two decades functional applications of monoclonal anti bodies in cancer therapy has increased tremendously. Initially it was emphasized mainly on improving the antibody protein in order to solve the immunogenicity problems and intensifying of the target antigen selection. In association to bare monoclonal antibodies, antibody-drug conjugates have been introduced in the form of targeted delivery system of effective anti-malignant agents in order to avoid the morbidity caused by conventional chemotherapy.

Cancer is considered as a leading killer worldwide even after a massive research is being reported on cancer therapy. As per $\mathrm{WHO}(2007)$ report, around seven million deaths occur with estimated sixteen million new cancer cases detected every year by 2020 [1]. Many attempts are under process to introduce therapeutic monoclonal antibodies into regular clinical use. Several admirable literatures are available related with the technology and development of therapeutic monoclonal antibodies [2-5].

In spite of FDA approval of several therapeutic monoclonal antibodies a number of problems remained unresolved. Among which, selection of true cancer cell specific antigen, improved enrollment of spectator cell lysing mechanism, and design of cheapest production technique. And attention is required to overcome these problems for more operative and monetary cancer therapy.

\section{Targeted Delivery and Monoclonal Antibodies}

Use of monoclonal antibodies alone has been discouraged now a days and attention is made on developing targeted delivery systems in order to avoid non-specific side effects associated with conventional cancer therapy [6]. Certainly it is expected that development of antibody-drug conjugates may become the focus of many pharmaceutical and biotech research and development programs in near future. Since the introduction and first time FDA approval of monoclonal antibody (Orthoclone OKT3 ${ }^{\circ}$ ) in 1992 against lymphoma for effective human cancer therapy, there has been lot of work on introducing additional antibodies into clinic is under progress [7].
In parallel to rise in the number of monoclonal antibodies, development of newer skills such as phage display libraries for the production these antibodies have arrived clinical trials and this fashion is expected to be reinforced as these approaches are further increased and validated. Successful development of monoclonal antibodies depends on technical competence to genetically engineered antibodies.

More detailed understanding of physiology of the target malignant cells as well as immune and non-immune effector tasks the antibody is expected to execute can appreciably bang on the essential molecular characteristics of the antibody. It is also essential to gain supplementary information about distribution of antigen in target and normal tissues, pharmacokinetic of antibody, efficiency in the target disease and uptake of antibody into solid malignant tissue for the rational selection of pilot antibody candidates, selection of suitable patient study group and effective design of expensive clinical trials.

\section{Conclusion}

The submissive combination of monoclonal antibodies meant to cell surface antigens on malignant cells has positively recognized itself as an effective approach for therapy of some solid and hematological tumors. A well categorized and authenticated antigens targeted by these antibodies provide us both the profits and ill effects of targeting them.

Overall conclusion from the above discussion is that targeted malignant therapies are balanced for an optimistic future. Monoclonal antibodies alone or in conjugation shows merit and demerits and a better acceptance of these parameters will permit a more coherent selection of antibodies for cancer target therapy. Thus, all the health care experts can look forward to be supplied with diversity of alternatives and have a scope to select a more effective and cheapest targeted treatment for different types of cancers.

\section{References}

1. Patil JS (2016) Advances in Drug Delivery Strategies for Cancer Therapeutics. J Pharmacovigil S3: e002

2. Oldham RK, Dillman RO (2008) Monoclonal antibodies in cancer therapy: 25 years of progress. J Cli Oncol 26: 1774-1777. 
Citation: Patil J (2016) Functional Applications of Monoclonal Antibodies in Cancer Therapy via Drug Targeting Approach. J Pharmacovigil 4: e163. doi:10.4172/2329-6887.1000e163

Page 2 of 2

3. Nissim A, Chernajovsky Y (2008) Historical development of monoclonal antibody therapeutics. Handb Exp Pharmacol 181: 3-18.

4. Yamada T (2011) Therapeutic monoclonal antibodies. Keio J Med 60: 37-46.

5. Scott AM, Wolchok JD, Old LJ (2012) Antibody therapy of cancer. Nat Rev Cancer 12: 278-287.
6. Gellerman G, Firer MA (2010) Targeted Drug Delivery in Cancer Therapeutics.

7. Nadler LM, Stashenko P, Hardy R, Kaplan WD, Button LN, et al (1980) Serotherapy of a patient with a monoclonal antibody directed against a human lymphoma-associated antigen. Cancer Res 40:3147-3154. 